\title{
ASTROCYTE SPECIFIC PROTEINS CONTENT IN THE DIFFERENT PARTS OF THE RAT AND MONGOLIAN GERBIL BRAIN DURING ONTOGENESIS
}

\author{
Y. P. KOVALCHUK ${ }^{凶}, H$. N. SHIYNTUM, G. A. USHAKOVA \\ Oles Honchar Dnipro National University, Ukraine; \\ 凶e-mail: yulka.5868152@ukr.net
}

Received: 28 October 2021; Accepted: 17 May 2021

\begin{abstract}
Astrocyte-specific proteins are used as markers of astrocytes, particularly in the case of age-related brain dysfunctions and neurodegenerative disorders. However, the data on the content of these proteins in different parts of the brain during ontogenesis are insufficient. In this research, the content of astrocyte specific $\mathrm{Ca}^{2+}$-binding protein $\mathrm{S100B}$ and glial fibrillary acidic protein (GFAP) in cerebellum, thalamus, and hippocampus of Wistar rats and Mongolian gerbils during ontogenesis were determined. Animals were divided by age into four groups ( $n=6-10)$ : 1 -newborn (1-day-old); 2 -30-day-old; 3 -90-day-old; 4 -180-day-old. Fractions of soluble and filamentous proteins from the different parts of the brain were obtained by differential centrifugation and solubilization with $4 M$ urea. The quantitative levels of S100B and GFAP were determined with ELISA. It was revealed that the content of S100B protein increased significantly by day 180 in all studied parts of the rat and gerbil brain. The content of GFAP both soluble and filamentous forms in the brain of 1 day-old animals was low, but raised significantly after 30 days in all studied parts of gerbil brain, and increased gradually up to 180 days in the rat brain. The magnitude of the increase in the content of the studied astrocyte-specific proteins was shown to be different and to depend on the brain part, postnatal development stage of the animals and their species.
\end{abstract}

Ke y w o rds: glial fibrillary acid protein, S100B, cerebellum, thalamus, hippocampus, ontogenesis.

$\mathrm{D}$ uring formation and maturation, the brain gradually develops and manifests astroglia. Astrocytes are the most common glial cells in the central nervous system (CNS) [1]. These glial cell types interact closely with neurons to provide structural [2], metabolic, and trophic [3] support and are actively involved in modulating the excitability of neurons and nerve impulses [4]. Astrocytes regulate neurotransmitter systems [5], synaptic processes [6], ion homeostasis [7], antioxidant protection [8], and energy metabolism [9]. According to current data, astrocytes also play a key role in conducting neuropathic pain [10]. Thus, functional changes in astrocytes can interact with surrounding cells, such as neurons and microglia [11]. Importantly, physiologic and pathologic properties of astrocytic metabolic plasticity bear translational potential in defining new potential diagnostic biomarkers and novel therapeutic targets to mitigate neurodegeneration and age-related brain dysfunctions [12].

The primary astrocyte proteins are calciumbinding protein S100B and glial fibrillary acidic protein (GFAP). GFAP is a histospecific component of the intermediate filaments (IF) of the cytoskeleton of astrocytes [13]. This protein provides structural support and tensile strength to the cytoskeleton of normal astrocytes [14]. The distribution of GFAP in different parts of the brain is uneven and depends on the number of astroglial cells: it is known that the content of astroglial cells in adult rats is maximum in the medulla oblongata (the complex of lower oils) and minimum in the cerebral cortex [13]. GFAP, as part of IF, plays an integral role in the migration of astrocytes and maintenance of the stable morphology of their processes during the development of reactive astrocytosis [15]. The use of GFAP as a mo- 
lecular index of neurotoxicity and a marker of nerve tissue damage has been proposed [16, 17]. Allegedly, this protein is involved in the molecular mechanisms of neuron-astrocyte interactions [18]. Due to its high specificity and early release from the CNS after traumatic brain injury, GFAP can be a very useful marker for early diagnosis [13]. The production of GFAP by astrocytes and the assembly of this protein into intermediate filaments interact with the $\mathrm{Ca}^{2+}$-regulated EF-hand proteins, $\mathrm{S} 100 \mathrm{~B}$, in a dosedependent manner [19].

The S100B protein was discovered by Moore [20] and is considered one of the nodal molecular components of complex intracellular systems that ensure the functional homeostasis of brain cells by combining and integrating various calciumdependent metabolic processes. Quantitative changes in S100B are currently regarded as a marker of brain damage (cortical, ischemic, etc.), metabolic disorders in the brain, or being under the influence of various factors in the body [20]. Characteristically, fluctuations in the concentration of S100B in the brain are not always accompanied by a marked deterioration in the somatic condition of animals, but, at the same time, these fluctuations can lead to various disorders of the integrative brain function, depending on the degree of hyperproduction of this protein.

Astrocyte dysfunction contributes to the development of psychiatric and neurodegenerative disorders [19, 20]. With age, the number of astrocyte-specific proteins increases; however, there are no quantitative data on the dynamics of the levels of these proteins in different parts of the brain in both laboratory animals and humans. This study aimed to investigate the redistribution and quantitative indicators of astrocyte-specific proteins, S100B and GFAP, in different parts of the brains of rats and Mongolian gerbils at different stages of ontogenesis.

\section{Materials and Methods}

This research was performed on 24 Wistar rats and 24 Mongolian gerbils. Animals were divided into four groups by age ( $n=6-10)$ : $1-$ newborn animals (1-day-old), 2 - 30-day-old, 3 - 90-day-old, 4 - 180-day-old. The rats and Mongolian gerbils were exposed to standard conditions with a natural change in lighting and adherence to the general diet. All animals had free access to food and water. The experiment was conducted in accordance with the "Regulations on the use of animals in biomedical experiments" [21].
At the end of the experiment, the animals were decapitated under anesthesia with sodium thiopental (40 mg/kg). Three brain sections - the cerebellum, thalamus, and hippocampus - were extracted and used to obtain protein fractions. To study astrocytespecific proteins differing in location, fractions containing soluble and filamentous proteins were obtained by differential centrifugation and solubilized with urea (4 M) [22]. The original buffer consisted of $25 \mathrm{mM}$ of Tris-HCl (pH7.4), $1 \mathrm{mM}$ of ethylenediaminetetraacetate (EDTA), $2 \mathrm{mM}$ of dithiothreitol, $0.2 \mathrm{mM}$ of phenylmethylsulfonyl fluoride (PMSF), and $3 \mathrm{mM}$ of sodium azide $\left(\mathrm{NaN}_{3}\right)$ (all from Sigma, USA).

The amount of total protein in the obtained fractions was determined as described by Bradford [23] and expressed in $\mathrm{mg} / 100 \mathrm{mg}$ of tissue.

The quantitative levels of GFAP and S100B in the cerebellum, thalamus, and hippocampus were determined using competitive solid-phase enzymelinked immunosorbent assay (ELISA), along with monospecific polyclonal antibodies against GFAP (Santa Cruz Biotechnology, USA, sc-32956-R) and S100B (Abcam, UK, ab 41548), peroxidase-labeled secondary anti-rabbit anti-IgG (Sigma, USA, A-6154) and the corresponding purified protein standards (Boehringer-Manheim, Germany and Sigma, USA) [24]. The obtained results were measured at $492 \mathrm{~nm}$ using an ELISA reader Anthos 2010 (Finland). The reference wavelength was $620 \mathrm{~nm}$. The amount of protein was expressed in $\mu \mathrm{g} / 100 \mathrm{mg}$ of tissue.

Statistical processing of the obtained data was performed using application packages Microsoft ${ }^{\circledR}$ Excel 2000 (Microsoft ${ }^{\circledR}$ ) and STATISTICA ${ }^{\circledR}$ for Windows 6.0 (StatSoft Inc.). Statistical analysis was carried out with one-way analysis of variance, ANOVA. Data at $P<0.05$ were considered statistically significant.

\section{Results and Discussion}

In the first part of the experiment, the total amounts of proteins in the cytosolic and $4 \mathrm{M}$ urea extracted cytoskeletal fractions obtained from different parts of the brains of rats and gerbils during postnatal development were investigated.

The total protein content in the cytosolic fractions from the different parts of the brain of newborn rats was $1.93-2.21 \mathrm{mg} / 100 \mathrm{mg}$ of tissue (Fig. 1, A).

In the cerebellum and thalamus, total protein contents gradually increased during the developmen- 
$\boldsymbol{A}$

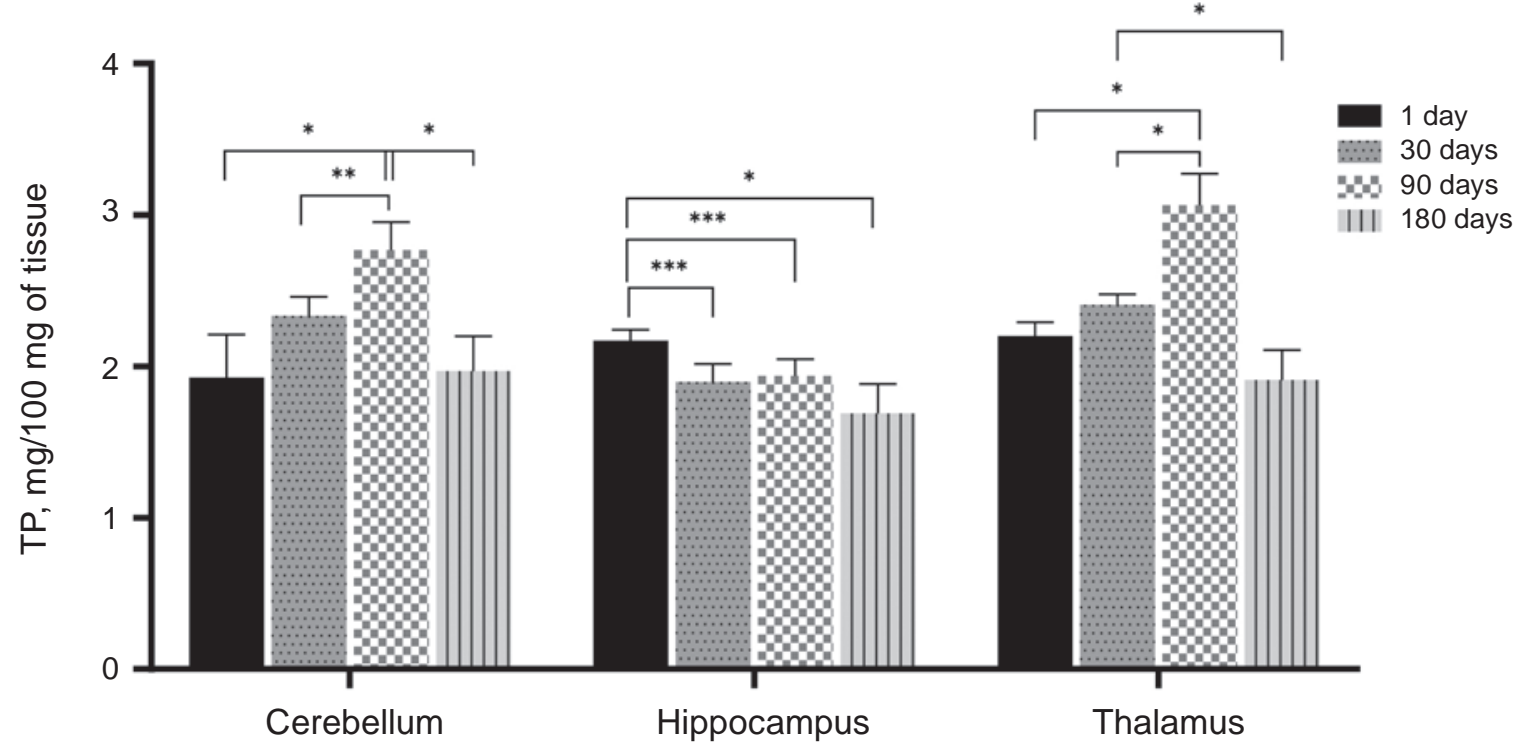

$B$

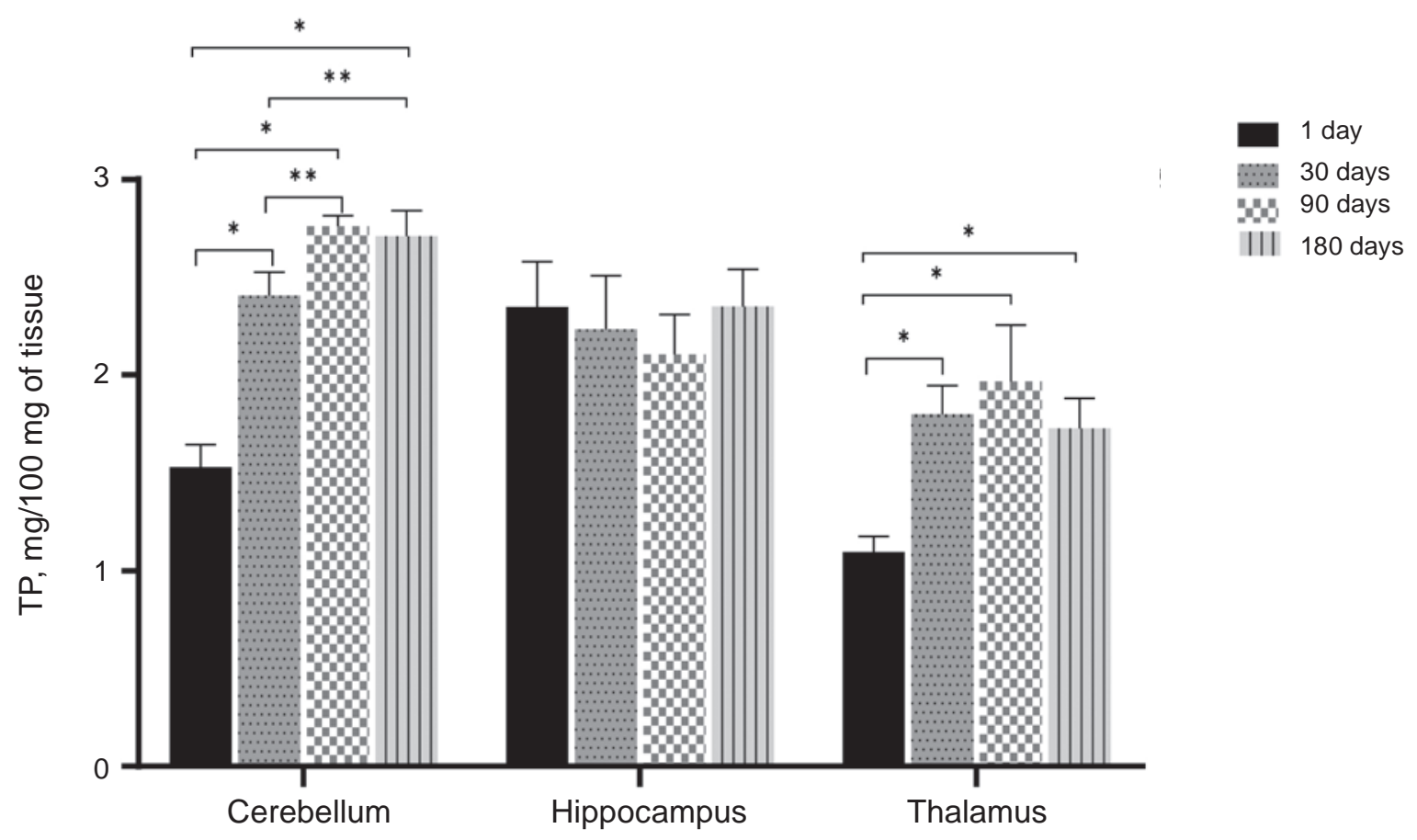

Fig. 1. The total protein (TP) content in cytosolic fractions obtained from different parts of the brain of rats (A) and of the brain of gerbils $(\boldsymbol{B})$ during postnatal development; $n=6-10$, *significance of differences, $P<0.01$, $* * P<0.03, * * * P<0.05$

tal period until day 90: $2.77 \pm 0.19 \mathrm{mg} / 100 \mathrm{mg}$ of tissue in the cerebellum and $3.07 \pm 0.21 \mathrm{mg} / 100 \mathrm{mg}$ of tissue in the thalamus. However, on the $180^{\text {th }}$ day of postnatal development, total cytosolic protein content in these brain areas significantly decreased, compared to levels in 90-day-old rats, however, it was not differed compare to the other studied time of postnatal development. The dynamics of the to- tal protein content in the hippocampus differed from those of the other brain parts, decreasing to $1.89 \pm 0.12 \mathrm{mg} / 100 \mathrm{mg}$ of tissue in 30-day-old rats and $1.49 \pm 0.09 \mathrm{mg} / 100 \mathrm{mg}$ of tissue in 180-day-old rats, compared to newborns.

In newborn gerbils, the level of total protein content in the cytosolic fractions ranged from 1.21 to $2.41 \mathrm{mg} / 100 \mathrm{mg}$ of tissue, with the highest 
rate observed in the hippocampus and the lowest in the thalamus (Fig. 1, B). Similar to the findings in rats, on day 30 of postnatal development, total protein content increased in the cerebellum (2.41 $\pm 0.12 \mathrm{mg} / 100 \mathrm{mg}$ of tissue) and thalamus (1.80 $\pm 0.15 \mathrm{mg} / 100 \mathrm{mg}$ of tissue) of gerbils but decreased in the hippocampus. The increase in the cerebellum and thalamus is probably due to the continuing anabolic processes in the direction of formation and maturation of certain structures in these parts of the brain after birth, unlike in the hippocampus, where structures are formed during embryogenesis [25]. In the thalamus, the total amount of cytosolic proteins reached its apex on day 30 of postnatal development and remained constant until day 180. In the cerebellum, this rate increased up to the $90^{\text {th }}$ day of postnatal development and stayed at $2.76 \pm 0.05 \mathrm{mg} / 100 \mathrm{mg}$ of tissue until the $180^{\text {th }}$ day. There were no significant changes in the hippocampus of gerbils during ontogenesis.

Studies of the total pool of proteins in the cytoskeletal fractions obtained from different parts of the brain of rats showed that levels in 1-day-old animals ranged from $0.58-0.94 \mathrm{mg} / 100 \mathrm{mg}$ of tissue (Fig. 2, A).

The total protein content in the cerebellum of 30-day-old rats increased significantly to $1.03 \pm 0.13 \mathrm{mg} / 100 \mathrm{mg}$ of tissue and doubled in the

A

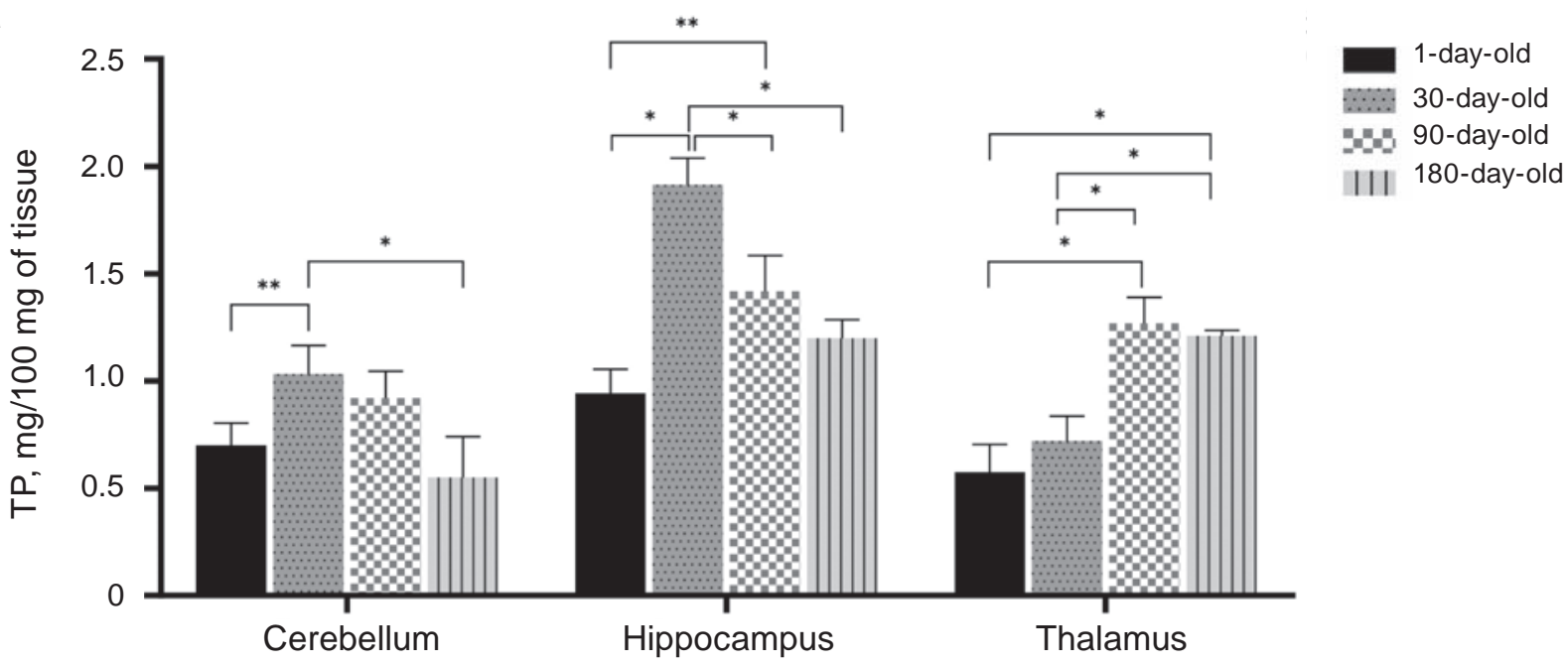

B

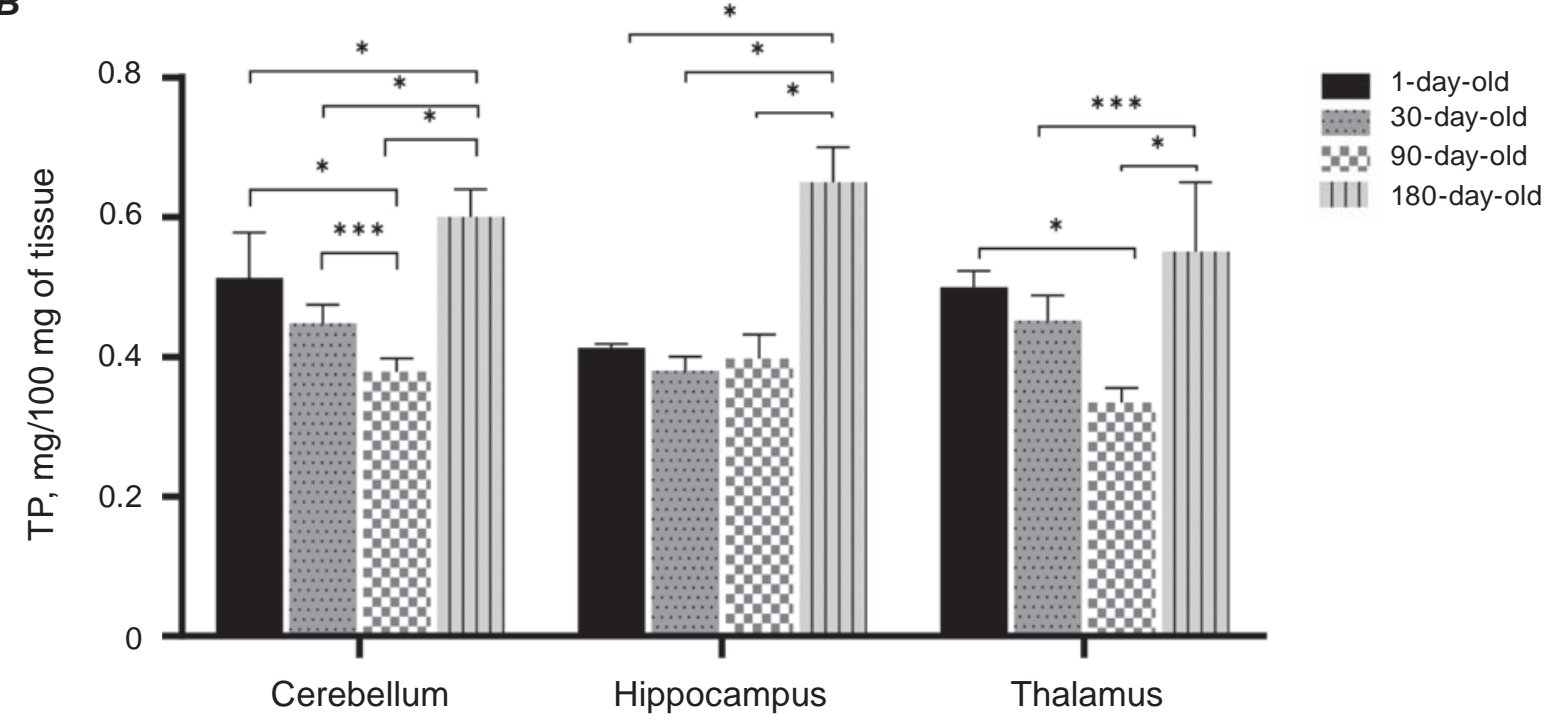

Fig. 2. The total protein (TP) content in the cytoskeletal fractions obtained from different parts of the brain of rats (A) and of the brain of gerbils (B) during postnatal development; $n=6-10$, *significance of differences, $P<0.01, * * P<0.03, * * * P<0.05$ 
hippocampus to $1.91 \pm 0.12 \mathrm{mg}$ per $100 \mathrm{mg}$ of tissue. In the thalamus, an increase in the total protein content was started from the $30^{\text {th }}$ day of postnatal development, but these data were not reliable because the total protein content fluctuated in a wide range.

The total cytoskeletal protein content decreased as in the cerebellum and hippocampus of 180-dayold rats compare to the 30-day-old. However, no significant changes were detected in these contents on day 90 and day 180. In the thalamus, this figure increased significantly on the $90^{\text {th }}$ day of postnatal development to $1.27 \pm 0.12 \mathrm{mg} / 100 \mathrm{mg}$ of tissue and remained constant at the developmental phase.

The results of the assessment of the total protein content in the cytoskeletal fraction of gerbils were ranging from $0.41-0.51 \mathrm{mg} / 100 \mathrm{mg}$ of tissue for all studied brain sections on the first day of postnatal development (Fig. 2, B). Then, this content gradually, but insignificantly, decreased by day 30 . In 90-dayold gerbils, there was a clear decreasing pattern in the cerebellum and thalamus, in contrast to the stable level in the hippocampus. On day 180 of postnatal development, the total protein content in all studied parts of the brain increased, with the highest rate in the hippocampus at $0.65 \pm 0.05 \mathrm{mg} / 100 \mathrm{mg}$ of tissue.

It was earlier investigated the intensity of the S100B protein biosynthesis during ontogenesis in humans and animals, revealing that the protein S100B appears at weeks 10-15 in different parts of the brain (cerebellum, pons, brainstem, midbrain, and spinal cord, and so on) of the human embryo [20]. By the $30^{\text {th }}$ week, the S100B protein accumulates in all parts of the CNS, except the frontal lobe, where the increase in protein content coincides with the appearance of the bioelectrical activity of the brain.

The accumulation of the S100B protein at the different stages of the ontogenesis of chickens, mice, and rats has also been studied in detail [26]. For example, in the brain of 3- to 15-day-old mice, the level of the S100B protein remains relatively low, then sharply increases from the 16th to the $22^{\text {nd }}$ day of postnatal development: it increases during this period by about 4-fold. A similar pattern has also been observed in the brain of rats, with the only difference being that the protein most intensely accumulates between the $16^{\text {th }}$ and $24^{\text {th }}$ days of postnatal development of the animal. The intensity of the S100B protein synthesis in the brain correlates with the level of mRNA in the corresponding parts of the brain.

In this study, we aimed to comparatively determine the levels of the S100B protein in different parts of the brains of rats and gerbils (Fig. 3, A), as previous data relate only to the total content of S100B in the brain.

We found that the level of this protein increased almost 4-fold in all evaluated regions of the brain (cerebellum, hippocampus, and thalamus) of rats on the $30^{\text {th }}$ day of postnatal development. In newborns, the content of the protein S100B in the cerebellum was $0.18 \pm 0.03 \mu \mathrm{g} / 100 \mathrm{mg}$ of tissue, in the hippocampus, it was $0.09 \pm 0.04 \mu \mathrm{g} / 100 \mathrm{mg}$ of tissue, and in the thalamus, it was $0.15 \pm 0.01 \mu \mathrm{g} / 100 \mathrm{mg}$ of tissue. In 30-day-old rats, the content of the S100B protein in the cerebellum increased to $0.51 \pm 0.03 \mu \mathrm{g} / 100$ $\mathrm{mg}$ of tissue, in the hippocampus, it increased to $0.46 \pm 0.02 \mu \mathrm{g} / 100 \mathrm{mg}$ of tissue, and in the thalamus, it increased to $0.49 \pm 0.02 \mu \mathrm{g} / 100 \mathrm{mg}$ tissue. S100B amounts also tended to increase in all studied parts of the brain of 90-day-old rats and increased significantly in the cerebellum $(2.24 \pm 0.13 \mu \mathrm{g} / 100 \mathrm{mg}$ of tissue), hippocampus $(1.90 \pm 0.11 \mu \mathrm{g} / 100 \mathrm{mg}$ of tissue), and thalamus $(1.38 \pm 0.04 \mu \mathrm{g} / 100 \mathrm{mg}$ of tissue) of 180-day-old rats.

Hiden et al. have demonstrated that the most intense biosynthesis of this protein occurs in the pyramidal cells of the hippocampus [27]. There is still a growing interest in the functional role of the S100B protein. The content of this protein increases during education and training of animals, which is confirmed by the fact that there is a more intensive inclusion of labeled amino acids in the S100B protein of the brain during the training period. It has also been shown that mice of inbred lines have a higher amount of the S100B protein in the brain, and these animals learn faster than control animals, in which the protein level in the brain is lower. Without a doubt, the S100B protein contained in neurons is primarily concentrated in the synaptic membranes and nucleoli of neurons.

Our studies of S100B in the cerebellum, hippocampus, and thalamus of gerbils during postnatal development showed that the dynamics of the content of this protein in all studied brain regions over 30 days were similar to those in rats (Fig. 3, B), but the content of the protein was itself lower in gerbils than in rats.

The content of S100B in the cerebellum of newborn gerbils was $0.08 \pm 0.003 \mu \mathrm{g} / 100 \mathrm{mg}$ of tissue, in the hippocampus, it was $0.05 \pm 0.001 \mu \mathrm{g} / 100 \mathrm{mg}$ of tissue, and in the thalamus, it was $0.06 \pm 0.005 \mu \mathrm{g} / 100$ $\mathrm{mg}$ of tissue. In 30-day-old gerbils, the level of this protein in the cerebellum increased to $0.31 \pm 0.01$ 
$\boldsymbol{A}$

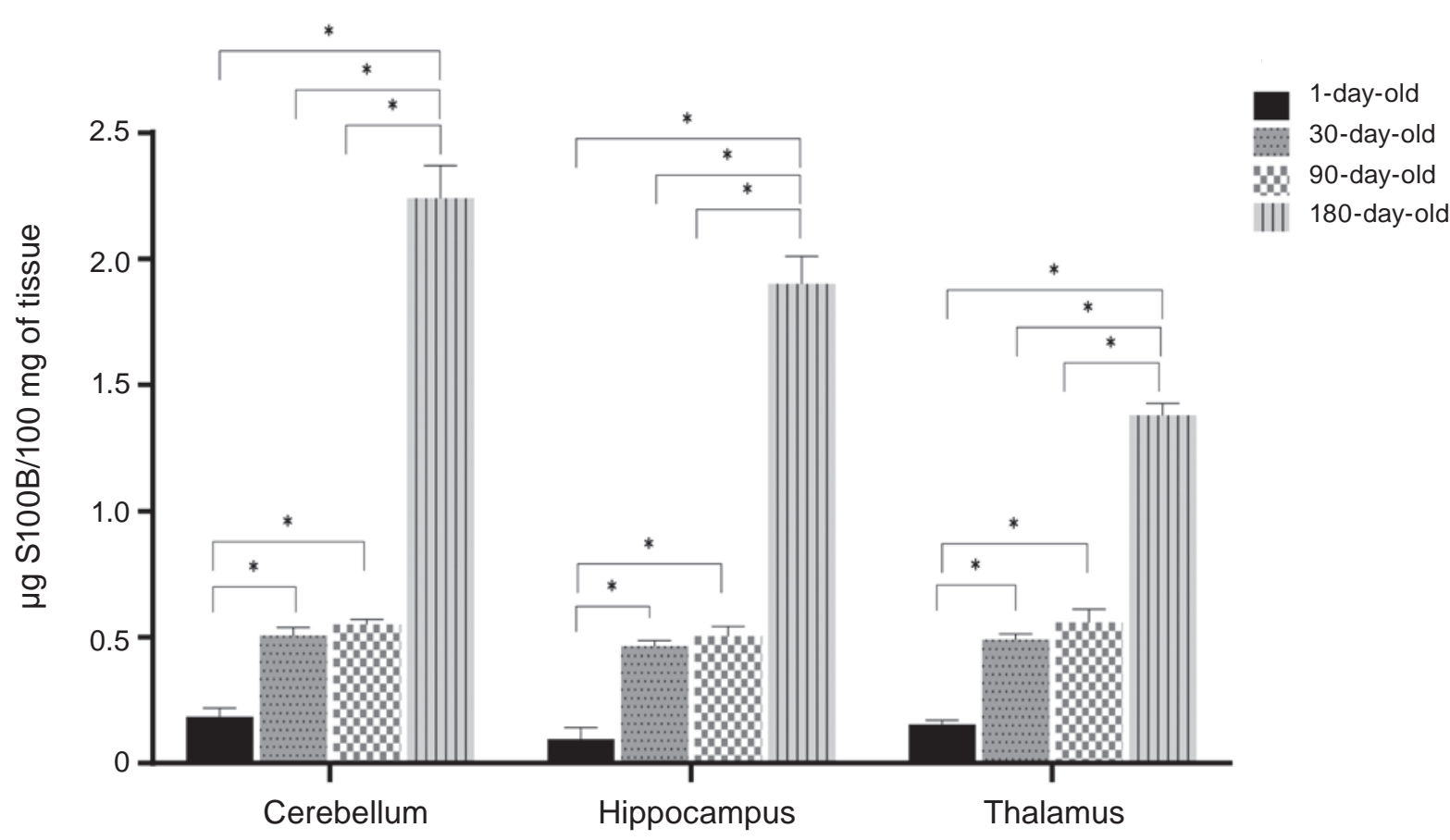

B

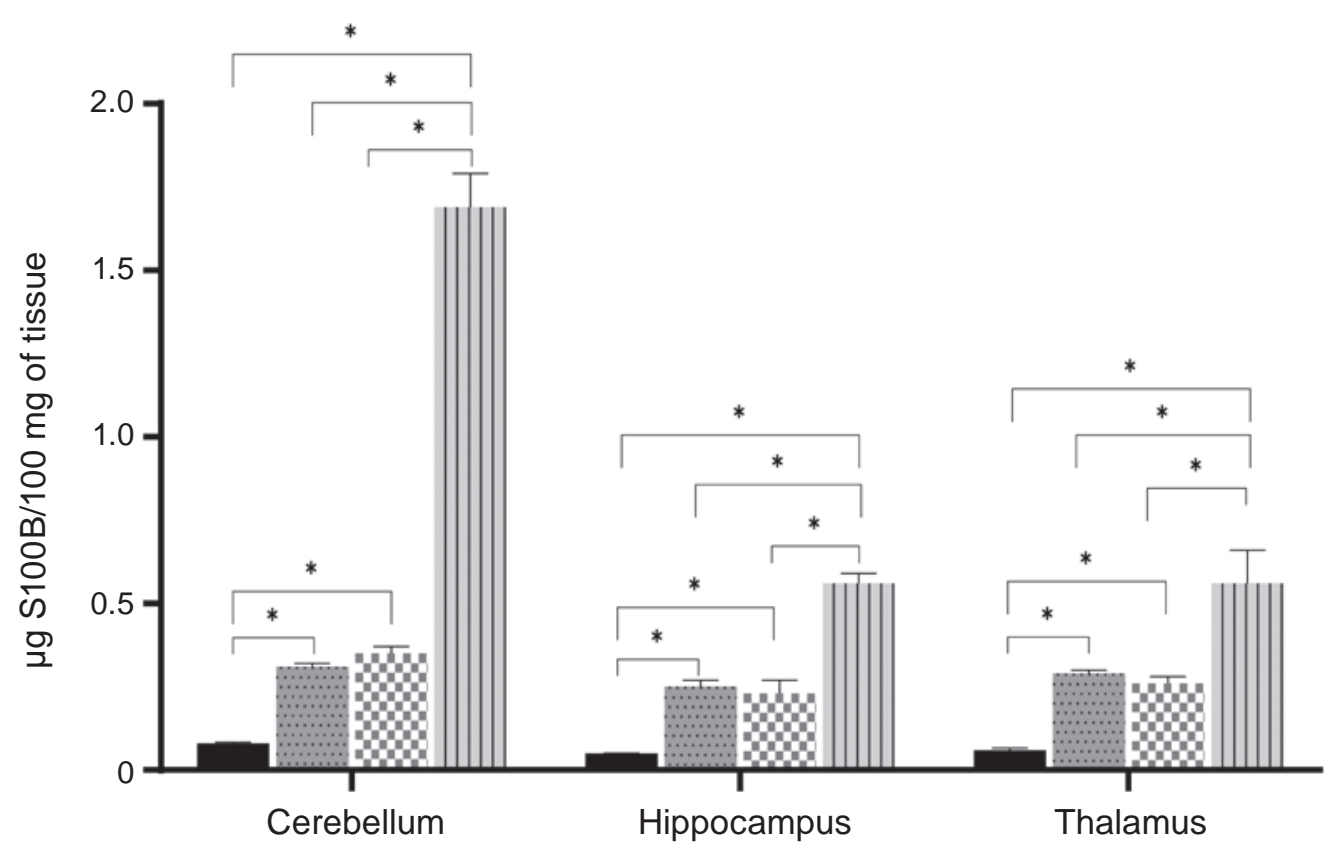

Fig. 3. The content of the S100B protein in different parts of the brain of rats (A) and the brain of gerbils (B) during postnatal development; $n=6$, * significance of differences, $P<0.01,{ }^{*} P<0.03$, ${ }^{* * *} P<0.05$

$\mu \mathrm{g} / 100 \mathrm{mg}$ of tissue, in the hippocampus, it rose to $0.25 \pm 0.02 \mu \mathrm{g} / 100 \mathrm{mg}$ of tissue, and in the thalamus, it was $0.29 \pm 0.01 \mu \mathrm{g} / 100 \mathrm{mg}$ of tissue. No significant changes were detected in the concentration of S100B in all three observed regions during the next 30 days of postnatal development. However, on day 180 , there were substantial increases in the protein contents in all studied parts of the gerbil brain - in the hippocampus, it was $0.56 \pm 0.03 \mu \mathrm{g} / 100 \mathrm{mg}$ tissue, in the thalamus, it was $0.56 \pm 0.11 \mu \mathrm{g} / 100 \mathrm{mg}$ of tissue, and in the cerebellum, the most significant change was registered at $1.69 \pm 0.11 \mu \mathrm{g} / 100 \mathrm{mg}$ of tissue. 


\section{A}

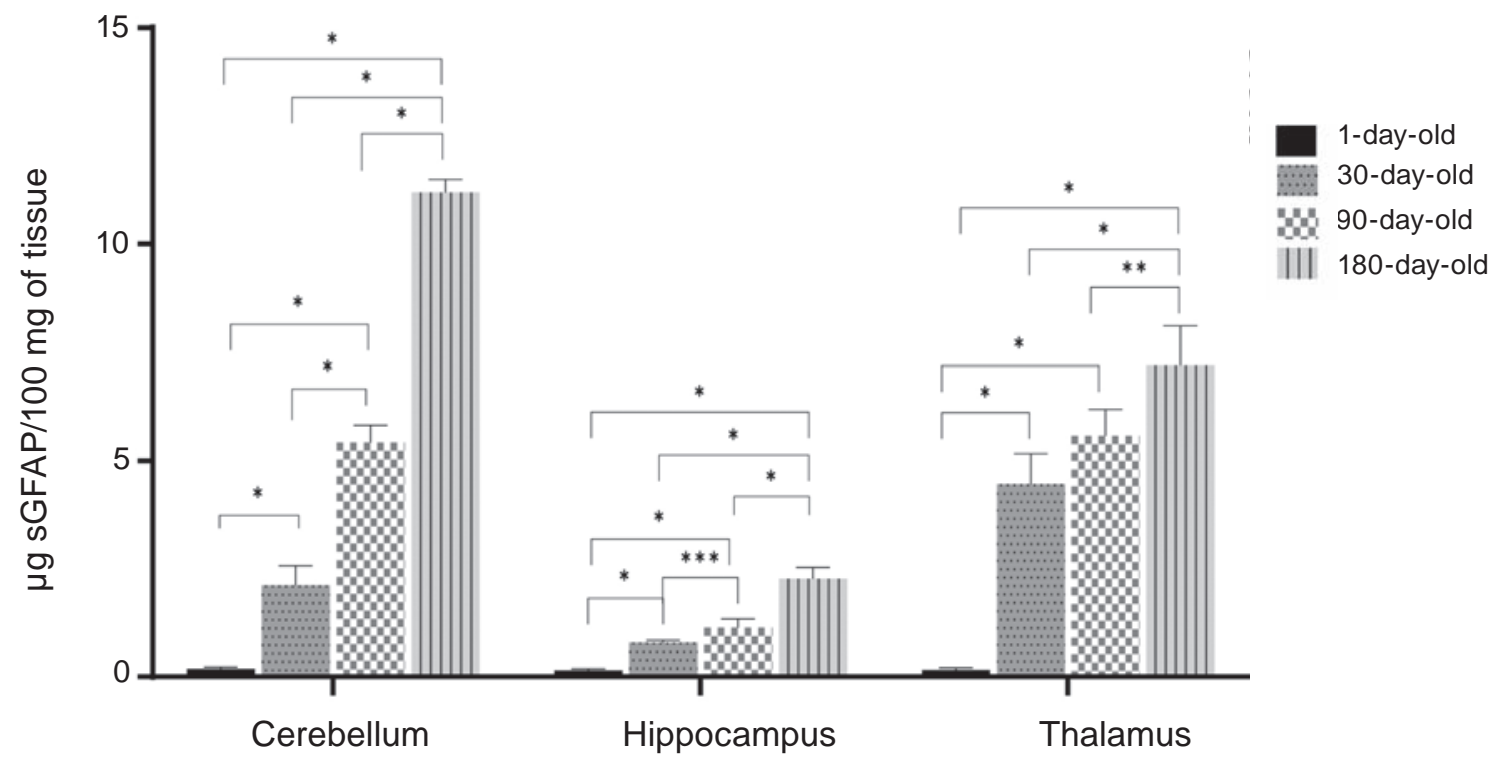

B

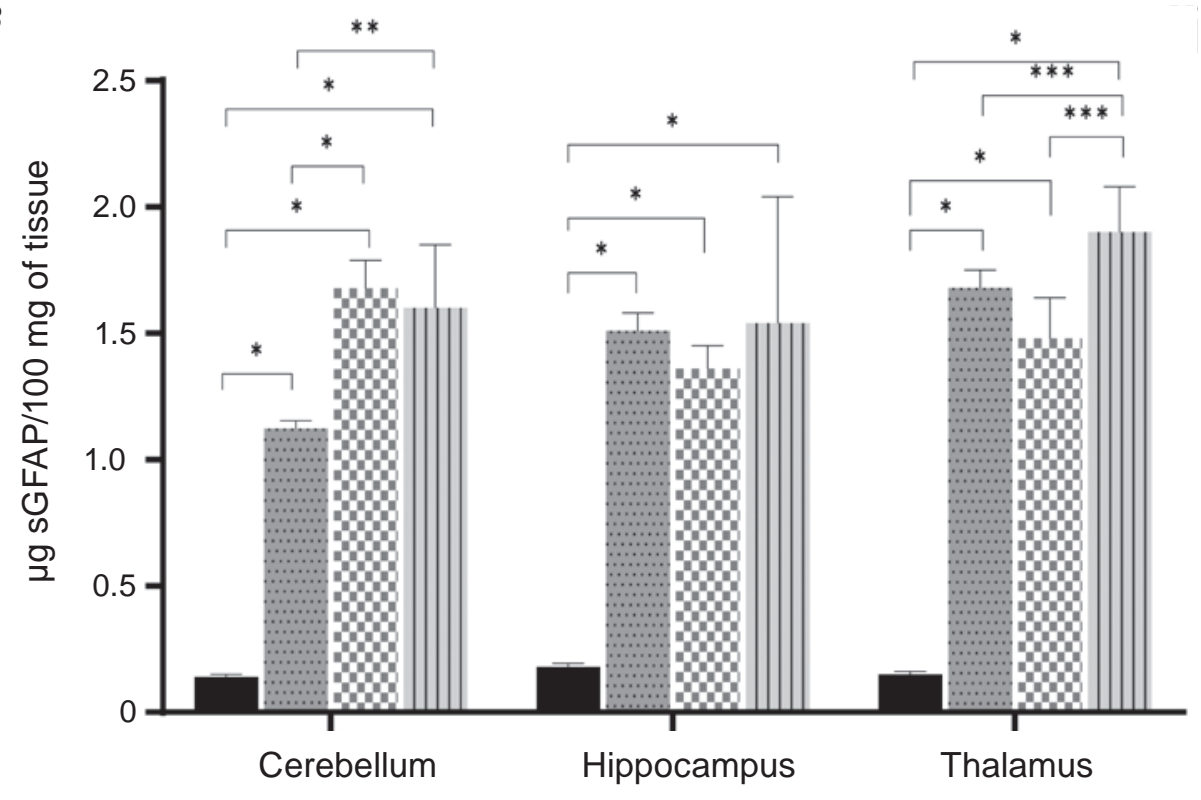

1-day-old 30-day-old W0-day-old

III 180-day-old

Fig. 4. The content of the soluble form of GFAP in different parts of the brain of rats (A) and the brain of gerbils (B) during postnatal development; $n=6$, *significance of differences, $P<0.01$, **P<0.03,*** $P<0.05$

The findings indicate an increase in S100B contents during 180 days of postnatal development. Literature data indicate that the level of this protein also increases with age. Brain aging is associated with the increased expression of the S100B gene and its mRNA in rats [28], as well as in the brains of neurologically healthy individuals [29]. However, available quantitative data on S100B in the aging brain are contradictory $[28,29]$. Moreover, according to some studies, the content of S100B and its mRNA, as well as the density of S100B-positive astrocytes in the hippocampus of mice, do not change with age
[30]. One study revealed that the level of S100B in the human cerebrospinal fluid also does not differ in healthy young and elderly people [31]. The increase in this protein in various parts of the brain at the later stages of ontogenesis is still an open question and requires a detailed study. In addition, as noted above [19], this protein is one of the regulators of the filamentous forms of the cytoskeleton and may have impact on GFAP contents.

Most of the work that has been carried out on the study of GFAP centers around its filamentous form, while in the investigation on the nature of 
changes in the ratio of fibrillated and soluble forms of GFAP, their polypeptide heterogeneity remains unclear [32]. GFAP is absent in the brain of newborn rats and unmyelinated white matter of the brain of infants, but with growth, it is synthesized and phosphorylated in glial cells after stimulation by hormones (norepinephrine) and various growth factors $[14,33]$.

In newborns, radial glia and immature astrocytes mostly express vimentin. However, during the maturation of nerve tissues in the early stages of development, vimentin is gradually replaced by GFAP in differentiated astroglial cells [34].

In this research, we evaluated the level of two forms (soluble and filamentous) GFAP in the cerebellum, hippocampus, and thalamus of rats and gerbils (Fig. 4, $A, B$ ).

A small amount of soluble GFAP was detected in newborn rats in all experimental areas of the brain. During the first month of the life of rats, there was a significant increase in the amount of sGFAP in the cerebellum $(2.12 \pm 0.45 \mu \mathrm{g} / 100 \mathrm{mg}$ of tissue) and hippocampus $(0.80 \pm 0.05 \mu \mathrm{g} / 100 \mathrm{mg}$ of tissue), but the most significant increase was observed in the thalamus $(4.46 \pm 0.70 \mu \mathrm{g} / 100 \mathrm{mg}$ of tissue). In 3-month-old experimental animals, we observed that the content of sGFAP in the cerebellum increased 2.5-fold compared with the amount in 1-month-old rats. sGFAP also increased in the hippocampus and thalamus compared with 1-month-old rats; however, these data were not reliable because the content of sGFAP fluctuated in a wide range. For 180-day-old animals, a significant increase in SGFAP in all parts of the brain of rats was observed; the content of sGFAP in the cerebellum was $11.19 \pm 0.30 \mu \mathrm{g} / 100 \mathrm{mg}$ of tissue, in the hippocampus, it was $2.27 \pm 0.26 \mu \mathrm{g} / 100 \mathrm{mg}$ of tissue, and in the thalamus, it was $7.20 \pm 0.90 \mu \mathrm{g} / 100 \mathrm{mg}$ of tissue.

Like in rats, low levels of the soluble form of GFAP were found in all studied parts of the brain of newborn gerbils, but these levels increased markedly within 30 days (Fig. 4, B). The content of sGFAP in the cerebellum of 30-day-old gerbils was $1.12 \pm 0.03 \mu \mathrm{g} / 100 \mathrm{mg}$ of tissue, but in 90-day-old animals, it increased to $1.67 \pm 0.11 \mu \mathrm{g} / 100 \mathrm{mg}$ of tissue and remained constant until 180 days. In contrast to the cerebellum, sGFAP in the hippocampus and thalamus of adult animals reached peak levels on day 30 of postnatal development, at $1.51-1.68 \mu \mathrm{g} / 100 \mathrm{mg}$ of tissue but did not change significantly by day 180 .

Findings on the content of the filamentous form of GFAP (fGFAP) in different parts of the brain of rats and Mongolian gerbils during ontogenesis are presented in Fig. $5(A, B)$.

There were low contents of this form in the cerebellum, hippocampus, and thalamus of newborn rats (Fig. 5, $A$ ).

In 30-day-old animals, fGFAP content increased considerably in all studied parts of the brain: in the cerebellum, it was $12.90 \pm 2.61 \mu \mathrm{g} / 100 \mathrm{mg}$ of tissue, in the hippocampus, it was $4.81 \pm 1.01 \mu \mathrm{g} / 100 \mathrm{mg}$ of tissue and in the thalamus, it was $5.40 \pm 1.01 \mu \mathrm{g} / 100$ $\mathrm{mg}$ of tissue. fGFAP also increased significantly in the hippocampus and thalamus of 90-day-old rats compared to their 1-month-old counter parts. The pattern in the cerebellum of 90-day-old rats was also that of an increase, compared to 1-month-old animals, but the data, in this case, were not reliable because the content of fGFAP fluctuated in a wide range.

In 180-day-old experimental animals, fGFAP markedly increased in all parts of the brain, compared to 90-day-old experimental rats; in the cerebellum, it was $31.90 \pm 4.21 \mu \mathrm{g} / 100 \mathrm{mg}$ of tissue, in the hippocampus, it was $24.01 \pm 2.50 \mu \mathrm{g} / 100 \mathrm{mg}$ of tissue, and in the thalamus, it was $39.40 \pm 0.72 \mu \mathrm{g} / 100 \mathrm{mg}$ of tissue.

Similar to the content in rats, fGFAP levels in all studied parts of the brain of newborn gerbils were also minimal (Fig. 5, $B$ ), which is consistent with the generally accepted fact that the process of the activation of the expression of the GFAP gene begins only after the birth of mammals [33].

During postnatal development in all parts of the brain of gerbils, there were substantial increments in the levels of fGFAP leading up to day 30: in the cerebellum, it was $22.30 \pm 2.01 \mu \mathrm{g} / 100 \mathrm{mg}$ of tissue, in the hippocampus, it was $46.91 \pm 3.02 \mu \mathrm{g} / 100 \mathrm{mg}$ of tissue, and in the thalamus, it was $35.21 \pm 3.01 \mu \mathrm{g} / 100 \mathrm{mg}$ of tissue. In 90 -day-old gerbils, fGFAP in the cerebellum increased to $34.70 \pm 1.21 \mu \mathrm{g} / 100 \mathrm{mg}$ of tissue and in the thalamus, it rose to $45.32 \pm 0.81 \mu \mathrm{g} / 100 \mathrm{mg}$ of tissue. The same rising tendency was also observed in the hippocampus, but this rise was insignificant compared to 1-month-old animals. In the thalamus of 180-day-old gerbils, the amount of fGFAP increased to $60.43 \pm 7.72 \mu \mathrm{g} / 100 \mathrm{mg}$ of tissue.

Age is directly related to numerous neurodegenerative brain disorders, and most of them are associated with astroglial dysfunctions [35]. Our findings show that changes occur in both the total protein content and the content of astrocyte-specific 
$A$

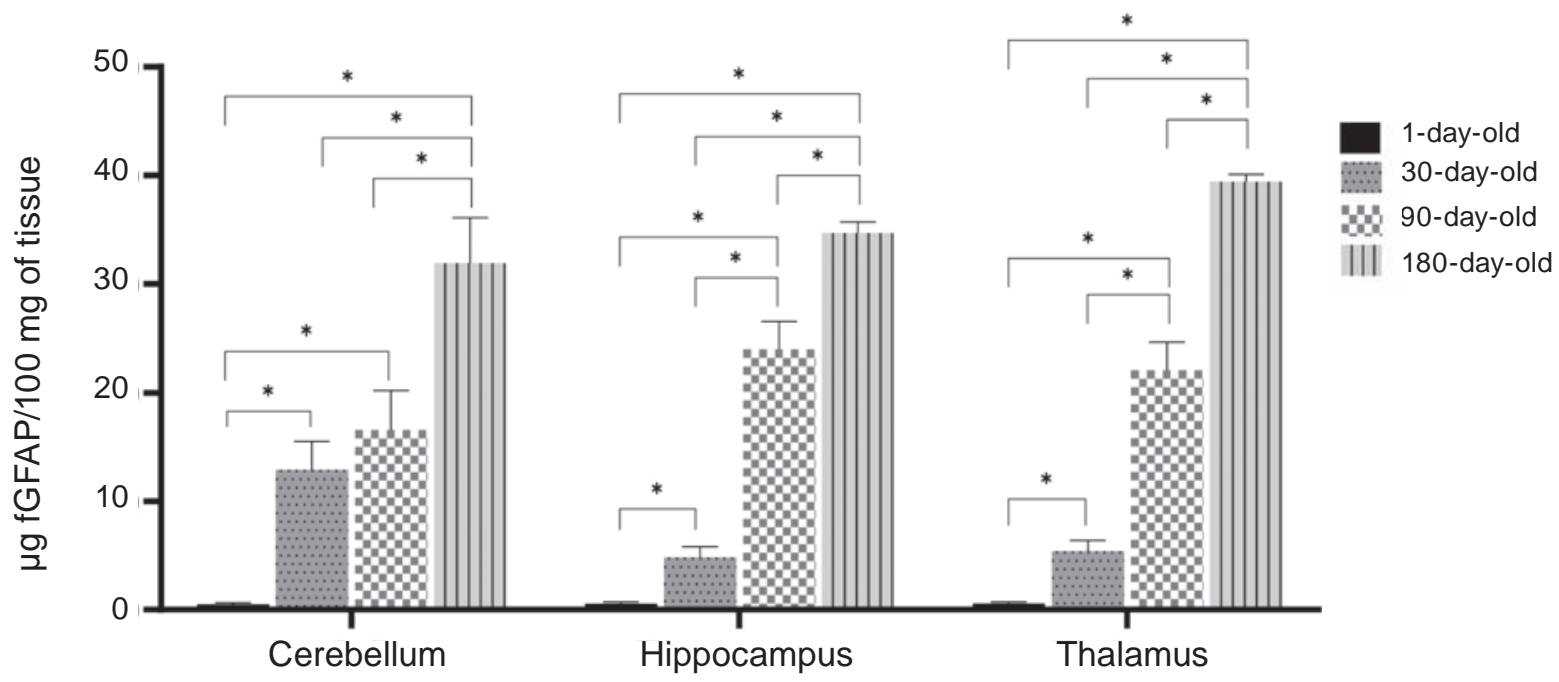

B

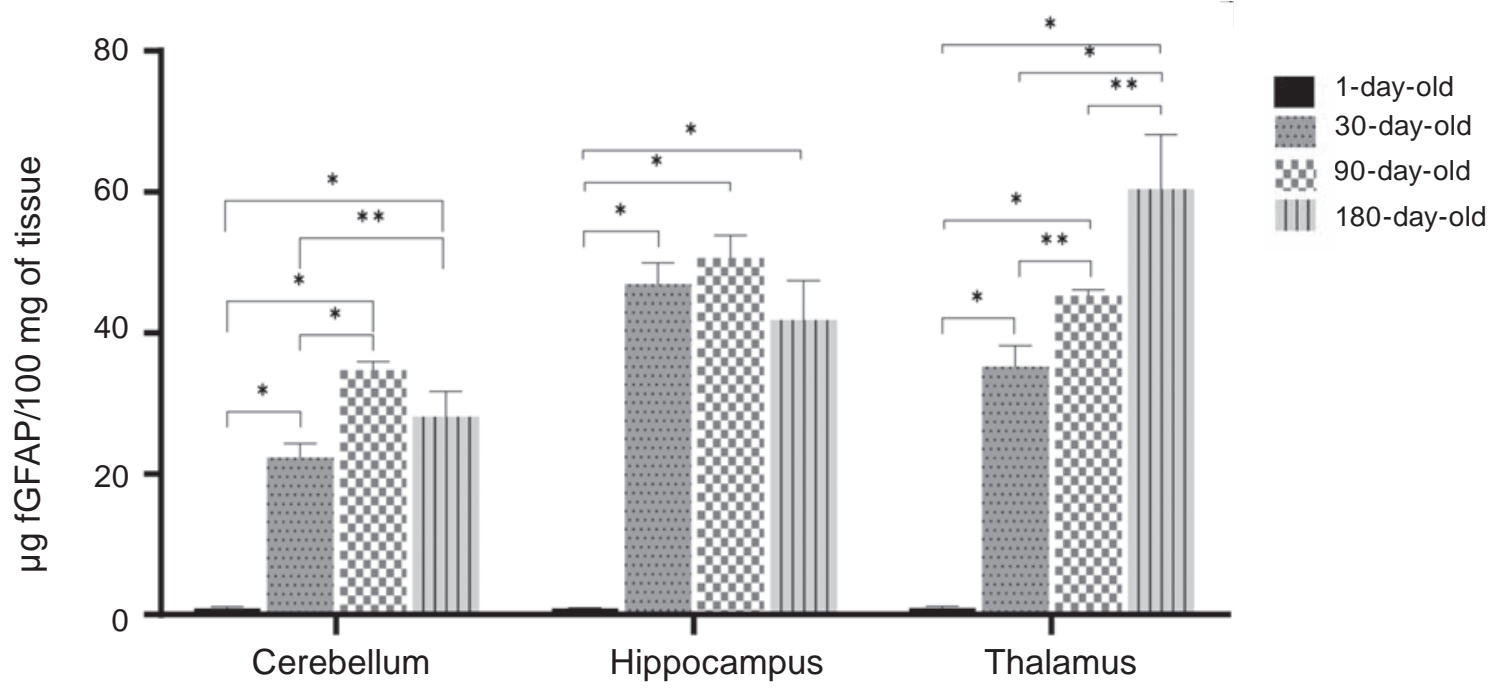

Fig. 5. The content of the filamentous form of GFAP in different parts of the brain of rats (A) and the brain of gerbils (B) during postnatal development; $n=6$, *significance of differences, $P<0.01, * * P<0.03, * * * P<0.05$

proteins, GFAP and S100B, in different parts of the brains of gerbils and rats depending on the period of postnatal development. Reportedly, during maturation and formation, the brain gradually develops and manifests astroglia. The results of this investigation suggest that the most intense development of astrocytes and the biosynthesis of GFAP occur in the cerebellum by the $90^{\text {th }}$ day of postnatal development of gerbils and rats, and in the thalamus and hippocampus, these processes occur earlier.

Conclusions. There are specific changes in both the total protein content and the content of astrocyte-specific proteins, soluble and filamentous forms of GFAP and calcium-binding protein S100B, in the different studied parts of the brains of gerbils and rats, and these changes depended on the term of postnatal development, brain`s area and animals' specie.

Conflict of interest. Authors have completed the Unified Conflicts of Interest form at http://ukrbiochemjournal.org/wp-content/uploads/2018/12/ coi_disclosure.pdf and declare no conflict of interest.

Funding. This work was supported by the Ministry of Education and Science of Ukraine (0120U102241). 


\section{ВМІСТ АСТРОЦИТСПЕЦИФІЧНИХ ПРОТЕЇНІВ У РІЗНИХ ВІДДІЛАХ ГОЛОВНОГО МОЗКУ ЩУРІВ ТА ПІЩАНОК ПІД ЧАС ОНТОГЕНЕЗУ}

\author{
Ю. П. Ковальчук \\ Г. О. Ушакова
}

\author{
Дніпровський національний університет \\ імені Олеся Гончара, Україна; \\ 凶e-mail: yulka.5868152@ukr.net
}

Астроцитспецифічні протеїни використовуються як маркери астрогліальних клітин, особливо у разі вікових дисфункцій мозку та нейродегенеративних розладів. Однак даних про вміст цих протеїнів у різних відділах мозку під час онтогенезу недостатньо. У роботі оцінено вміст астроцитспецифічних $\mathrm{Ca}^{2+}$ зв'язувального протеїну S100B та гліального фібрилярного кислого протеїну (GFAP) у мозочку, таламусі та гіпокампі щурів лінії Wistar і монгольських піщанок під час онтогенезу. Тварин було поділено на чотири групи $(n=6-10)$ віком 1, 30, 90 та 180 днів після народження відповідно. Фракції розчинних та філаментних протеїнів із різних ділянок мозку отримували шляхом диференційного центрифугування та солюбілізації 4М сечовиною. Кількісний вміст S100B та GFAP визначали з використанням IEA. Показано, що вміст протеїну S100B суттєво збільшувався до 180-го дня в усіх досліджуваних відділах головного мозку щурів та монгольських піщанок. Вміст розчинної та філаментної форм GFAP у мозку одноденних тварин був низьким, проте через 30 днів значно зростав в усіх відділах головного мозку піщанок та збільшувався поступово в мозку щурів впродовж 180 днів після народження. Показано, що підвищення вмісту досліджуваних астроцитспецифічних протеїнів було різним залежно від відділу мозку, стадії постнатального розвитку тварин та їх виду.

К л ю ч в і с л о в : гліальний фібрилярний кислий протеїн, S100B, мозочок, таламус, гіпокамп, онтогенез.

\section{References}

1. Chandrasekaran A, Avci HX, Leist M, Kobolák J, Dinnyés A. Astrocyte differentiation of human pluripotent stem cells: new tools for neurological disorder research. Front Cell Neurosci. 2016; 10: 215.
2. Gigase FAJ, Snijders GJLJ, Boks MP, de Witte LD. Neurons and glial cells in bipolar disorder: A systematic review of postmortem brain studies of cell number and size. Neurosci Biobehav Rev. 2019; 103: 150-162.

3. Phatnani H, Maniatis T. Astrocytes in neurodegenerative disease. Cold Spring Harb Perspect Biol. 2015; 7(6): a020628.

4. Galland F, Seady M, Taday J, Smaili SS, Gonçalves CA, Leite MC. Astrocyte culture models: Molecular and function characterization of primary culture, immortalized astrocytes and C6 glioma cells. Neurochem Int. 2019; 131: 104538.

5. Morioka N, Zhang FF, Nakamura Y, Kitamura T, Hisaoka-Nakashima K, Nakata Y. Tumor necrosis factor-mediated downregulation of spinal astrocytic connexin43 leads to increased glutamatergic neurotransmission and neuropathic pain in mice. Brain Behav Immun. 2015; 49: 293-310.

6. Bosworth AP, Allen NJ. The diverse actions of astrocytes during synaptic development. Curr Opin Neurobiol. 2017; 47: 38-43.

7. Fleischer W, Theiss S, Slotta J, Holland C, Schnitzler A. High-frequency voltage oscillations in cultured astrocytes. Physiol Rep. 2015; 3(5): e12400.

8. Fernandez-Fernandez S, Almeida A, Bolaños JP. Antioxidant and bioenergetic coupling between neurons and astrocytes. Biochem J. 2012; 443(1): 3-11.

9. Verkhratsky A, Nedergaard M. Physiology of Astroglia. Physiol Rev. 2018; 98(1): 239-389.

10. Liang Y, Qiu Y, Du J, Liu J, Fang J, Zhu J, Fang J. Inhibition of spinal microglia and astrocytes contributes to the anti-allodynic effect of electroacupuncture in neuropathic pain induced by spinal nerve ligation. Acupunct Med. 2016; 34(1): 40-47.

11. Kuter K, Olech Ł, Głowacka U. Prolonged dysfunction of astrocytes and activation of microglia accelerate degeneration of dopaminergic neurons in the rat substantia nigra and block compensation of early motor dysfunction induced by 6-OHDA. Mol Neurobiol. 2018; 55(4): 3049-3066.

12. Morita M, Ikeshima-Kataoka $H$, Kreft $M$, Vardjan N, Zorec R, Noda M. Metabolic plasticity of astrocytes and aging of the brain. Int J Mol Sci. 2019; 20(4): 941. 
13. Wilhelmsson U, Pozo-Rodrigalvarez A, Kalm M, de Pablo Y, Widestrand Å, Pekna M, Pekny M. The role of GFAP and vimentin in learning and memory. Biol Chem. 2019; 400(9): 1147-1156.

14. Tykhomyrov AA, Pavlova AS, Nedzvetsky VS. Glial fibrillary acidic protein (GFAP): on the $45^{\text {th }}$ anniversary of its discovery. Neurophysiology. 2016; 48(1): 54-71.

15. Pfuhlmann K, Schriever SC, Legutko B, Baumann P, Harrison L, Kabra DG, Baumgart EV, Tschöp MH, Garcia-Caceres C, Pfluger PT. Calcineurin A beta deficiency ameliorates HFD-induced hypothalamic astrocytosis in mice. $J$ Neuroinflammation. 2018; 15(1): 35.

16. O'Callaghan JP, Sriram K. Glial fibrillary acidic protein and related glial proteins as biomarkers of neurotoxicity. Expert Opin Drug Saf. 2005; 4(3): 433-442.

17. Brenner M. Role of GFAP in CNS injuries. Neurosci Lett. 2014; 565: 7-13.

18. Pierozan P, Zamoner A, Soska ÂK, de Lima BO, Reis KP, Zamboni F, Wajner M, PessoaPureur R. Signaling mechanisms downstream of quinolinic acid targeting the cytoskeleton of rat striatal neurons and astrocytes. Exp Neurol. 2012; 233(1): 391-399.

19. Garbuglia M, Verzini M, Sorci G, Bianchi R, Giambanco I, Agneletti AL, Donato R. The calcium-modulated proteins, S100A1 and $\mathrm{S} 100 \mathrm{~B}$, as potential regulators of the dynamics of type III intermediate filaments. Braz J Med Biol Res. 1999; 32(10): 1177-1185.

20. Beharier O, Kahn J, Shusterman E, Sheiner E. S100B - a potential biomarker for early detection of neonatal brain damage following asphyxia. $J$ Matern Fetal Neonatal Med. 2012; 25(9): 15231528.

21. Medical ethics and human rights: provisions on the use of animals in biomedical experiments. Exp Clin Physiol Biochem. 2003; 22(2): 108-109. (In Ukrainian).

22. Fomenko OZ, Ushakova GO, Pierzynowski SG. Proteins of astroglia in the rat brain under experimental chronic hepatitis and 2-oxoglutarate effect. Ukr Biokhim Zhurn. 2011; 83(1): 69-76.

23. Bradford MM. A rapid and sensitive method for the quantitation of microgram quantities of protein utilizing the principle of protein-dye binding. Anal Biochem. 1976; 72(1-2): 248-254.
24. Ngo TT, Lenhoff GM, Yaklich A. ELISA. Moscow: Mir, 1998. 444 p. (In Russian).

25. Liutenko MA. Morphological features of the development of the cerebellum of nonbred white rats at the stage of early ontogenesis. SCIARTICLE.RU. 2014; (9): 161-164. (In Russian).

26. Kruijff S, Hoekstra HJ. The current status of S-100B as a biomarker in melanoma. Eur J Surg Oncol. 2012; 38(4): 281-285.

27. Nedzvetsky VS, Nerush PA. Cognitive deficiency and imbalance of expression of neurospecific proteins in streptozotocin-induced diabetes. Neurosci Theor Clin Aspect. 2005; 1(1): 35-38. (In Russian).

28. Linnemann D, Skarsfelt T. Regional changes in expression of NCAM, GFAP, and S100 in aging rat brain. Neurobiol Aging. 1994; 15(5): 651-655.

29. Sheng JG, Mrak RE, Rovnaghi CR, KozlowskaE, Van Eldik LJ, Griffin WS. Human brain S100 beta and S100 beta mRNA expression increases with age: pathogenic implications for Alzheimer's disease. Neurobiol Aging. 1996; 17(3): 359-363.

30. Wu Y, Zhang AQ, Yew DT. Age related changes of various markers of astrocytes in senescenceaccelerated mice hippocampus. Neurochem Int. 2005; 46(7): 565-574.

31. Peskind ER, Griffin WS, Akama KT, Raskind MA, Van Eldik LJ.Cerebrospinal fluid S100B is elevated in the earlier stages of Alzheimer's disease. Neurochem Int. 2001; 39(56): 409-413.

32. Massaro AN, Chang T, Kadom N, Tsuchida T, Scafidi J, Glass P, McCarter R, Baumgart S, Vezina G, Nelson KB. Biomarkers of brain injury in neonatal encephalopathy treated with hypothermia. $J$ Pediatr. 2012; 161(3): 434-440.

33. Yang Z, Wang KKW. Glial fibrillary acidic protein: from intermediate filament assembly and gliosis to neurobiomarker. Trends Neurosci. 2015; 38(6): 364-374.

34. Bramanti V, Tomassoni D, Avitabile M, Amenta F, Avola R. Biomarkers of glial cell proliferation and differentiation in culture. Front Biosci (Schol Ed). 2010; 2(2): 558-570.

35. Gómez-Gonzalo M, Martin-Fernandez $M$, Martínez-Murillo R, Mederos S, HernándezVivanco A, Jamison S, Fernandez AP, Serrano J, Calero P, Futch HS, Corpas R, Sanfeliu C, Perea G, Araque A. Neuron-astrocyte signaling is preserved in the aging brain. Glia. 2017; 65(4): 569-580. 